\author{
竹囲年 延*1, 油田 信 -*2

\section{Control of a Conected Two-link Mobility by One Joint Actuator} \\ Toshinobu TAKEI*3 and Shin'ichi YUTA \\ ${ }^{* 3}$ School of Systems and Information Engineering, University of Tsukuba, \\ 1-1-1 Ten'noudai, Tsukuba-shi, Ibaraki, 305-8573 Japan

\begin{abstract}
A target of our research is a conected two-pole-link mechanism with one controllable joint. The one link is long and the another one is short. The long link is jointed to the center of the short link with an actuated joint. We call the long link upper-body, and the short one lower-body. In initial condition, upper-body stands vertically and lower-body lies on the ground. This mechanism is expected to be able to move by swinging its upper body and rolling its lower-body, from that initial posture. In this paper, we propose some control laws and algorithms, for the model of this underactuated mechanism, and give means for aplication to a actual experimental machine. And, we show results of the moving motions in experiments by actual machine.
\end{abstract}

Key Words : Two-link-one-motor Robot, Dynamical Locomotion, Control of a Under-actuated Mechanism, Simulator for Actual Machine, Experiment in Actual Machine

\section{1. え がき}

二つの棒状のリンクよりなり, 大きいリンクの端が 小さいリンクの中心に繋がっていて, そのジョイント にトルクを与える事のできるメカニズを考える. 小さ いリンクを下体と呼び, 大きいリンクを上体と呼ぶ. これらのリンクに重力下で地面と垂直な面で運動をさ せる. 初期状態では下体は地面に横たわっており, 上 体は垂直な姿勢で起きているとする.これらの 2 リ ク間のジョイントを操作して, 上体をほぼ垂直に保っ たまま，下体を一端を支点に地面から起き上がらせ回 転させた後, 再び地面に着地させる.この動作には, 不連続なシステムの変化が含まれており,また, その 実現には劣駆動システムの制御が必要である ${ }^{(1)}$.

本稿では, この制御対象について解析し, モデル化 されたシステムの上で目標の動作を実現する為の制御 則を提案する. さらに，その制御則を実機へ実装する 際の対応について述べ，実際に作製した実機上で行っ た実験結果について報告する.

\section{2. 問 題 設 定}

$2 \cdot 1$ 制御対象とするメカニズム 本研究で対象 とするのは, 二つの大小の棒状リンクと一つのアク

* 原稿受付 2006 年 5 月 29 日.

*1 筑波大学システム情報工学研究科( $305-8573$ つくば市天 王台 1-1-1).

*2 正員, 筑波大学機能工学系.

E-mail : takei@roboken.esys.tsukuba.ac.jp
チュエータから構成されてる2リンク 1 モータ機構で ある. 大きいリンク (上体)の一端が小さいリンク (下 体)の中心に連結し，そのジョイントにはモータと減 速機が取り付けられている. 下体は地面に接している が固定されてはいない. 下体の両端は先を丸くしてお き，下体が回転するとそれに伴い支点が移動する.メ カニズムのモデルを図 1 に示す.

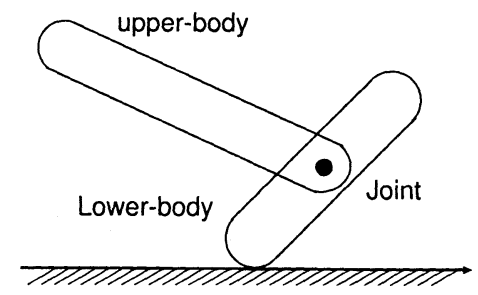

Fig. 1 A model of the considered robot

$2 \cdot 2$ 目標とする動作 このメカニズムに, 上体 を振る事で図2(a) (f) に示す下体に垂直面内の起きあ がりや回転の運動を行わせ, 傾斜の無い平らな面で 1 次元の移動を実現する.

〈1〉 静止している初期姿勢 (図 2(a)) から上体を等速 で倒し込む (図 2(b)).

$\langle 2\rangle$ 上体が傾いて, 静的に不安定に近い姿勢になっ たところで，上体を逆の方向へ振る. それにより， 上体を起こす反作用で，下体を端点を接地させな 


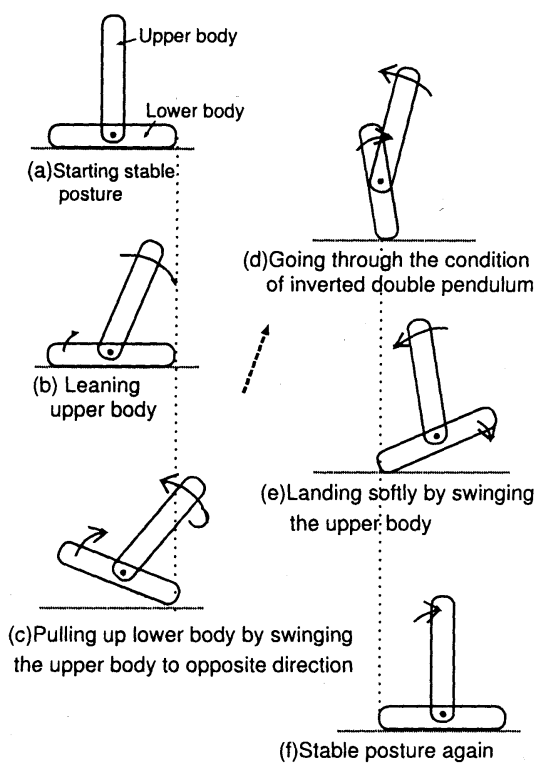

Fig. 2 Proposed motion of the two link mechanism

がら地面から起き上がらせる (図 2(c)).

〈3〉適切なトルクをジョイントに与える事により， 下体を起こし回転させて, 上体と下体が交差した 後 (図 2(d)), 下体を再び地面に横たえさせる (図 2(e)). 下体の着地に当たっては角速度を十分に減 速しソフトな着地を行なわせる. この間，上体に は直立に近い姿勢を維持させる.

〈4〉下体が着地した後, 上体を再び垂直にし, 静止 させる (図 2(f)).

\section{3. 目標動作の解析}

図 2 の(a)(b)(f) は下体が横たわっていて，上体のみ が運動する状態である. (c)(d)(e) は下体が一点で接地 し上体と下体が共に運動している状態である.これら の動作を解析する為, 各々の状態について運動方程式 を求める.ここで地面と下体の間の角度を $\theta_{1}$ とし上 体と下体間の角度を $\theta_{2}$ とする。

3.1 下体が横たわっている時の方程式 下体が 地面に横たわっていて上体の 1 リンクのみの運動は

$$
\begin{aligned}
\tau & =\left(I_{2}+m_{2}\left(r l_{g 2} \sin \theta_{2}+l_{g 2}{ }^{2}+l_{g 1} l_{g 2} \cos \theta_{2}\right)\right) \ddot{\theta}_{1} \\
& +\left(I_{2}+I_{r} G_{p}^{2}+m_{2} l_{g 2}{ }^{2}\right) \ddot{\theta}_{2}+m_{2} l_{g 2} g \cos \theta_{2}
\end{aligned}
$$

で記述される.ここで, 各パラメータを表 1 に示す.

3.2 下体が一点で支えられている時の方程式 下 体が端点支持の時は，二重振子にモデル化される．下 体の両端は半径 $\mathrm{r}$ の円弧形状を持つので, 下体の回転
Table 1 Parameters used in equation of motion

\begin{tabular}{|l|l|}
\hline $\mathrm{r}$ & The radius of end of the lower link \\
\hline$l_{g 1}$ & The half length between centers of two wheels \\
\hline$l_{g 2}$ & $\begin{array}{l}\text { The length from joint to gravity center of upper } \\
\text { body }\end{array}$ \\
\hline$m_{1}$ & weight of lower body \\
\hline$m_{2}$ & weight of upper body \\
\hline$I_{1}$ & lower body moment of inertia \\
\hline$I_{2}$ & upper body moment of inertia \\
\hline$I_{r}$ & motor rotor moment of inertia \\
\hline$G_{p}$ & gear ratio \\
\hline
\end{tabular}

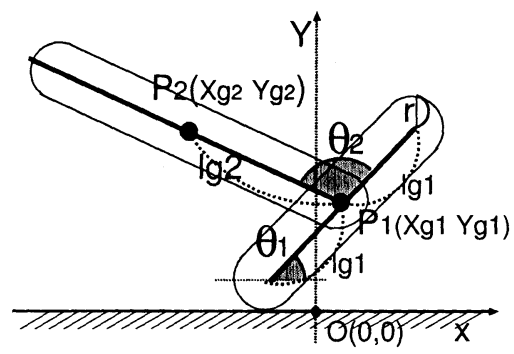

Fig. 3 A math model for the mechanism

に伴いその角度 $\theta_{1}$ が変化すると接地点も $r \theta_{1}$ だけ移 動する. この倒立振子モデルについてオイラ・ラグラ ンジェ方程式により運動方程式

$$
\begin{aligned}
& 0=\alpha_{11} \ddot{\theta}_{1}+\alpha_{12} \ddot{\theta}_{2}+h_{1}\left(\dot{\theta}_{1}, \dot{\theta}_{2}, \theta_{1}, \theta_{2}\right) \\
& \tau=\alpha_{21} \ddot{\theta}_{1}+\alpha_{22} \ddot{\theta}_{2}+h_{2}\left(\dot{\theta}_{1}, \dot{\theta}_{2}, \theta_{1}, \theta_{2}\right)
\end{aligned}
$$

が求まる.ここで,

$$
\begin{aligned}
\alpha_{11} & =I_{1}+I_{2}+m_{1}\left(r^{2}+2 r l_{g 1} \sin \theta_{1}+l_{g 1}{ }^{2}\right) \\
& +m_{2}\left(r^{2}+2 r l_{g 2} \sin \left(\theta_{1}+\theta_{2}\right)+r l_{1} \sin \theta_{1}\right. \\
& \left.+l_{g 1}^{2}+l_{g 2}^{2}+2 l_{g 1} l_{g 2} \cos \theta_{2}\right) \\
\alpha_{12} & =I_{2}+m_{2}\left(r l_{g 2} \sin \left(\theta_{1}+\theta_{2}\right)+l_{g 1} l_{g 2} \cos \theta_{2}+l_{g 2}{ }^{2}\right) \\
h_{1} & =m_{1} g l_{g 1} \cos \theta_{1} \\
& +m_{2} g\left(l_{g 1} \cos \theta_{1}+l_{g 2} \cos \left(\theta_{1}+\theta_{2}\right)\right) \\
& +\left(r \cos \left(\theta_{1}+\theta_{2}\right)-l_{g 1} \sin \theta_{2}\right) m_{2} l_{g 2}\left(2 \dot{\theta}_{1} \dot{\theta}_{2}+\dot{\theta}_{2}^{2}\right) \\
& +r\left(m_{1} l_{g 1} \cos \theta_{1}\right. \\
& \left.+m_{2}\left(l_{g 1} \cos \theta_{1}+l_{g 2} \cos \left(\theta_{1}+\theta_{2}\right)\right)\right) \dot{\theta}_{1}^{2} \\
\alpha_{21} & =I_{2}+m_{2}\left(r l_{g 2} \sin \left(\theta_{1}+\theta_{2}\right)+l_{g 2}{ }^{2}+l_{g 1} l_{g 2} \cos \theta_{2}\right) \\
\alpha_{22} & =I_{2}+I_{r} G_{p}^{2}+m_{2} l_{g 2}{ }^{2} \\
h_{2} & =m_{2} l_{g 2} g \cos \left(\theta_{1}+\theta_{2}\right)+l_{g 1} l_{g 2} m_{2} \sin \theta_{2} \dot{\theta}_{1}^{2}
\end{aligned}
$$

であり，てはジョイントに作用するトルクである.こ れらの式の中の各パラメータ物理量を表 1 に示す. 


\section{3 下体が横たわっている状態から一点支持状態へ} 移る条件 下体が横たわっている時, 上体の姿勢と 角速度, さらに, 与えるトルクによっては下体が回転 して起き上がり，一点支持の状態へと遷移する.

2 リンクの運動方程式 (2)(3) を, 下体の角加速度 $\ddot{\theta}_{1}$ について解くと

$$
\begin{aligned}
\ddot{\theta}_{1} & =\frac{1}{D}\left(-h_{1} \alpha_{22}-\alpha_{12}\left(\tau-h_{2}\right)\right) ; \\
D & =\alpha_{11} \alpha_{22}-\alpha_{12} \alpha_{21}
\end{aligned}
$$

を得る.この式に下体が横たわっている(すなわち $\left.\theta_{1}=0, \dot{\theta}_{1}=0\right)$ として, 上体のみの運動方程式 (1) か ら求まる $\dot{\theta}_{2}$ と $\theta_{2}$ を代入して得た, 下体の角加速度が

$$
\ddot{\theta}_{1}>=0
$$

となるとき， $\dot{\theta}_{1}$ が正の值となり，下体が地面に横た わっている姿勢から，左回りに起き上がり一点支持状 態へと遷移する. 一方, 右回りに起き上がる条件は, 下体が横たわっている条件を $\left(\theta_{1}=0+\pi, \dot{\theta}_{1}=0\right)$ とし て計算した下体の角加速度が $\ddot{\theta}_{1}<0$ となる時である.

3.4 一点支持状態からの着地一点支持の状態 において $\theta_{1}$ が増加して $\theta_{1}=\pi$ となるのが着地であ る. 下体の着地時に, 下体の速度が大きいと, 下体 に大きな着地衝撃が加わり，機体には跳ねが生じる， 従って，着地の直前には，下体の角速度を十分に減速 しておく必要がある．着地する下体の角速度が十分に 小さく，跳ね返りがないとすれば，着地瞬間に $\theta_{1}$ は $\theta_{1}=\pi, \dot{\theta}_{1}=0$ に固定され, 運動方程式は (2)(3) 式か ら (1) 式へ遷移する

\section{4. 制御方法の提案}

このメカニズムのジョイントのモータトルクを適切 に制御する事により，節 $2 \cdot 2$ で示した目標動作を行わ せる. ここでは, そのための制御の方法を提案する.

\section{$4 \cdot 1$ 概要}

1. 下体が横たわっている状態：上体が垂直に立って いる初期姿勢から, 上体を等角速度制御して踏切 条件まで前へ傾ける．この間上体は一定速度で回 転させる．これを実現する制御則を制御モード 1 と呼ぶ.

2. 一点支持状態への踏み切り：上体が前方に倒れ, 自然に一点支持状態となる姿勢に近づいたところ に踏切条件を定める. この姿勢で, 次の倒立振子 状態の制御則を適用すると, ジョイントには上体 を振り上げるトルクが与えられるので, 自動的に 踏み切る事になり，一点支持状態に遷移する．な お, この踏切条件は次の一点支持状態の初期条件
となるので, 劣駆動倒立振子の制御パラメータと 合わせて決定する必要がある.

3. 一点支持の状態：システムを式(2)(3) で表される 非線形な劣駆動である倒立二重振子として制御 し，上体の姿勢維持と下体の回転を行わせ，踏切 条件の状態から着地状態へ移行させる．この非線 形システムに対し， $\theta_{1}-\tau$ 間の関係を部分線形化 し, 下体の PD 制御を行って ${ }^{(2)}$ 下体の姿勢を角度 $\pi$ に変化させる.ここで, 制御ゲインは, 下体が 軟着陸を行い, かつ, 踏切条件と合わせて, 着地 時の上体の姿勢と速度が，その後の安定を維持で きる範囲に入るように決定する. 機体が一点支持 状態の間の制御を制御モード 2 と呼ぶ.

4. 着地時の衝撃緩和：制御モード 2 では, $\theta_{1}=\pi$ と なる着地時に，同時に下体の地面に対する角速度 白 地時には若干の速度が残り, 着地直前で $\theta_{1}$ は完 全に0ではない，そこで，着地時に $\dot{\theta}_{1}$ が突然 0 となる事のショックを上体が受ける影響を軽減す る為, 着地の瞬間にはジョイントの摩擦補償のみ を行って上体がフリーに動く状態とし，それによ り上体が受ける衝撃を軽減する。

5. 下体が横たわった状態：上体を PD制御し，垂直 な姿勢で静止させる. 下体が地面に付いた後で上 体の姿勢を垂直にする制御則をモード 3 と乎ぶ.

4.2 制御モード 2 制御モード 2 は劣駆動なメ カニズムの制御である．ここでは，下体の部分線形化 (2)の手法を適用し，下体のみをフィードバック制御す

る.いま，ジョイントに加えるトルクを

$$
\tau=\frac{-\alpha_{22} h_{1}+\alpha_{12} h_{2}}{\alpha_{12}}+\left(\alpha_{21}-\frac{\alpha_{11} \alpha_{22}}{\alpha_{12}}\right) u
$$

で与えるとすると，式(2)(3) より

$$
\begin{aligned}
& \ddot{\theta}_{1}=u \\
& \ddot{\theta}_{2}=\frac{-h_{1}-\alpha_{11} u}{\alpha_{12}}
\end{aligned}
$$

となり， $\theta_{1}$ の動きは線形二次の方程式を満たす．ここ で，下体を水平な状態 $\theta_{1}=0$ から端点を支点にして 起こし回転させ再び地面に軟着地 $\left(\theta_{1}=\pi\right)$ させる為, $u$ を $\theta_{1}$ の PD 制御で与えることとし

$$
u=-k_{p}\left(\theta_{1}-\pi\right)-k_{v} \dot{\theta}_{1} \quad\left(k_{v}>0, k_{p}>0\right)
$$

とすると $\ddot{\theta}_{1}$ は

$$
\ddot{\theta}_{1}=-k_{p}\left(\theta_{1}-\pi\right)-k_{\nu} \dot{\theta}_{1}
$$

なる式で与えられる運動をする，モード2へと遷移し た時間を 0 とし，下体が回転後，再び地面に着く時間 
を T とする. 着地時の条件は

$$
\left|\dot{\theta}_{1}(T)\right|<V_{\min }
$$

である.ここで, V min は着地時の下体の許容速度で ある.

この制御では, この条件と, さらに, 着地時まで上 体が上を向いた姿勢を維持し, 着地後に安定して静止 できる範囲に入っているように, フィードバックパラ メータ $k_{p}$ と $k_{v}$ が選ばれる必要がある.

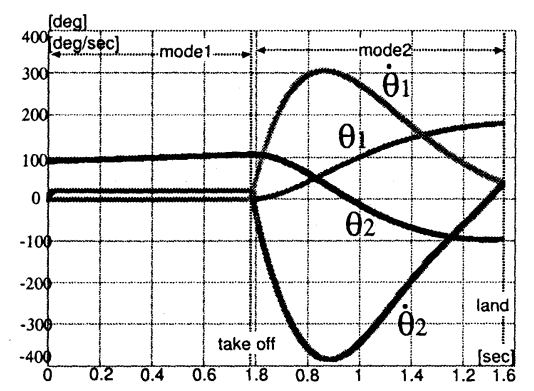

Fig. $4 \theta_{1} \dot{\theta}_{1} \theta_{2} \dot{\theta}_{2}$ of simulation results in model and mode2

4.3 制御モード 2 に於ける適切な制御パラメータ と踏切条件の探索上述したモード2の制御では下 体はフィードバック制御されているが，上体は式 (6) で与えられるトルクを式 (3)に与えて, 式 (2) と式 (3)

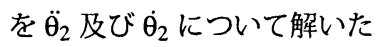

$$
\begin{aligned}
& \ddot{\theta}_{2}=\frac{-h_{1}-\alpha_{11}\left(k_{p}\left(\theta_{1}-\pi\right)-k_{v} \dot{\theta}_{1}\right)}{\alpha_{12}} \\
& \dot{\theta}_{2}=\int_{0}^{T} \ddot{\theta}_{2} d t+\dot{\theta}_{2}(0), \theta_{2}=\int_{0}^{T} \dot{\theta}_{2} d t+\theta_{2}(0)
\end{aligned}
$$

に従った運動を行う.ここで, 上体の部分線形化フィー ドバック制御のゲイン $k_{p}$ と $k_{v}$ ，及び，この制御の初 期条件である，制御モード 1 から制御モード 2 への踏 切条件 $\dot{\theta}_{2}(0)$ と $\theta_{2}(0)$ を注意媣く調整し, 下体が着地 する時間 Tにおいて, $\dot{\theta}_{2}(T)$ と $\theta_{2}(T)$ が適切な範囲に 入るように定める.ここで決定された， $\dot{\theta}_{2}(0)$ が制御 モード1において上体を傾倒させる際の目標角速度と なる.

これらの 4 つのパラメータは解析的に定める事はで きないので, シミュレーションによる探索を行う. 探 索により求めた適切なフィードバックゲインと踏み切 り条件を用いて制御した時の, 上体と下体の角度及び 角速度の一例を図 4 に示す．この例では着地時に，下 体の角速度は十分減速され，上体はほぼ直立で角速度 が小くなっている.

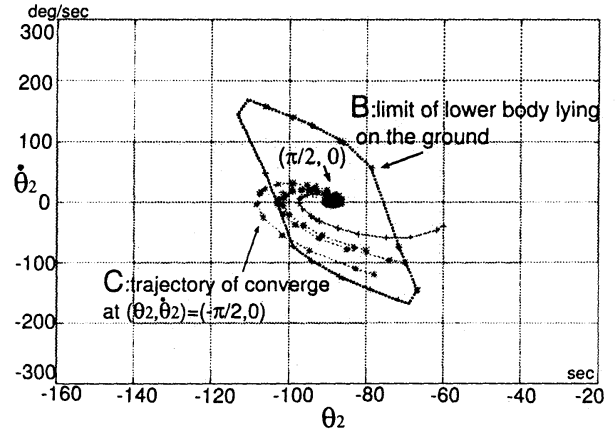

Fig. 5 tarajectories of converge at $(\pi / 2,0)$ with a limit of lower body lying on the ground in a graph of $\theta_{2}$ and $\dot{\theta}_{2}$ on mode 3

4.4 制御モード 3 上体の角度 $\theta_{2}$ に対し垂直な 姿勢を目標值として与え, フィードバック制御を行う. ジョイントに与えるトルクは

$$
\tau=-k_{q}\left(\theta_{2}+\frac{\pi}{2}\right)-k_{r} \dot{\theta}_{2},\left(k_{q}>0, k_{r}>0\right)
$$

である. 着地時の, 上体の傾き $\theta_{2}(T)$ や角速度 $\dot{\theta}_{2}(T)$ が大きいとフィードバック制御により垂直状態に静止 させる間に, 下体が再び浮き上がったり, また, さらに それより機体が転倒する可能性がある. 上体の式 (13) による制御中に下体が再び浮いてしまう姿勢及び角速 度の条件は式 (4) と式 (13) から計算できる.

その条件を満たす範囲の一例を $\theta_{2}-\dot{\theta}_{2}$ 位相面上に 示したのが図 5 の太い線で囲まれた部分 B である. 一 方, フィードバックゲイン $k_{q} k_{r}$ を定めると, 位相面 上のある点を初期位置として上体に $\mathrm{PD}$ 制御を行った 時に垂直に静止するまでの軌跡は式 (1) と式(13)より 求められ, この例では, 図 5 中のCで与えられる. 範 囲 B の中からはみ出ない軌跡 Cが, 下体が浮かない で上体が垂直に静止する軌跡である.

この条件より, 着地時の姿勢と角速度を始点として, それが垂直に静止するまでの軌跡が，範囲 B からはみ 出ない $\mathrm{PD}$ 制御ゲイン $k_{q}$ と $k_{r}$ を決定する.

\section{5. 実機への対応}

5.1 詳細なシミュレータによるパラメータ決定 実際のシステムには，モデルにはない要素を含み，モ デルとずれが生じる. しかし, その影響はそれ程大き くないと仮定できる，とくに，上で提案した方法は， 基本的にフィードバック制御によっているので多少の 変動は吸収して制御が実現されると期待される. しか し, モード 2 の劣駆動系の制御の部分には, オープン ループの要素が含まれているので, これに対しては適 


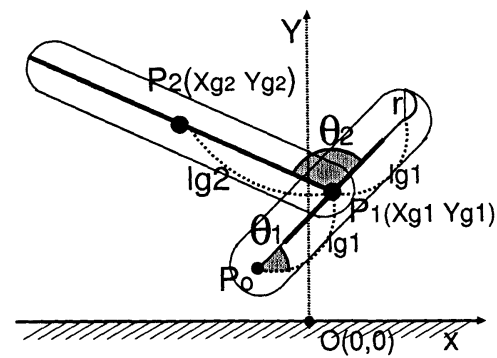

Fig. 6 Mechanical model of two link mechanism without touching ground

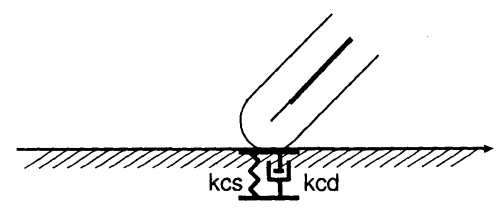

Fig. 7 Mechanical model of two link mechanism when touching ground

切な考慮が必要である.

そこで，原則として，上に提案した制御法を適用し， モード 2 の制御におけるパラメータ $\left(k_{p}, k_{v}\right)$ とモード 1 からモード 2 へ遷移する踏切条件を実機にあうよう に適切に定めることによって制御を行う事にする.す なわち, これらのパラメータの探索において, 十分に 詳細なシミュレーションを行って, 適切なパラメータ を決定する事とする.

なお，実機のジョイント間に存在している摩擦は， 実測により摩擦トルクを求めて, 各制御則で算出した トルクからその分を加えたトルクを制御の段階でジョ イントに与える事とする.

実機を対象とする時, 上記のモデルとの差異の比較 的大きな要素は次に述べる項目である. ここでは, そ れらに対応するシミュレーションの方針を示す.

5.2 運動方程式の拡張 制御法の提案では, 下 体は常に地面に寝ているかあるいは一点で支持されて いるとした. しかし, 実機には, 着地時にはバウンド があり上体と下体が共に, 宙に浮く間が生じる. 従っ て, シミュレーションの為のモデルは, 下体が寝て地 面に接している状態と一点接地の状態, そして下体の どの点も地面に触れず宙に浮いている状態とその間の 遷移がシミュレートできなければならない.

これらの3つの状態を連続してシミュレーションを する為には, 床に対して固定点を持たない重力場の浮 遊 2 リンクの運動方程式に, 各状態での拘束条件に よって動く力と衝突で発生する力を追加し足し合わせ
る(4)事でシミュレーションを行う．また，下体リンク と地面との着地衝突としてシミュレーションする必要 があり, 地面と下体の間の弾性を局所的バネ・ダンパ 系として取り扱う.

5.2.1 宙に浮いている時２つのリンクが宙に浮 いている時, 重心回りの各リンクの並進と回転に関す る運動方程式は

$$
\begin{aligned}
& I_{1} \ddot{\theta}_{1}=-\tau \\
& I_{2}\left(\ddot{\theta}_{1}+\ddot{\theta}_{2}\right)=\tau+P_{12} \times \boldsymbol{F} \\
& m_{1} \ddot{P}_{1}=-\boldsymbol{F}-\left[\begin{array}{c}
0 \\
m_{1} g
\end{array}\right] \\
& m_{2} \ddot{\boldsymbol{P}}_{2}=\boldsymbol{F}-\left[\begin{array}{c}
0 \\
m_{2} g
\end{array}\right]
\end{aligned}
$$

で与えられる.ここで, 上の式で用いられているパラ メータとジョイント間に㗢く力は

$$
\begin{aligned}
& \boldsymbol{P}_{1}=\left[\begin{array}{l}
x_{g 1} \\
y_{g 1}
\end{array}\right] \\
& \boldsymbol{P}_{12}=\lg _{2}\left[\begin{array}{l}
\cos \left(\theta_{1}+\theta_{2}\right) \\
\sin \left(\theta_{1}+\theta_{2}\right)
\end{array}\right] \\
& \boldsymbol{P}_{2}=\boldsymbol{P}_{1}+\boldsymbol{P}_{12} \\
& \boldsymbol{F}=\left(\frac{m_{1} m_{2}}{m_{1}+m_{2}}\right) \ddot{\boldsymbol{P}}_{12}
\end{aligned}
$$

である.

5.2.2 バネ・ダンパを持つ一点接地時の運動方程式 地面とリンクの衝突時の運動は, 接触点に垂直軸には バネ・ダンパモデル (図 7) に基づいて計算される反発 力, 及び, 水平軸には滑べらずに転がる拘束力 $F_{1}$ を, 与えてシミュレーションを行うのが良い. この時, 並 進及び回転の運動方程式 (22) (25) となる.

$$
\begin{aligned}
& I_{1} \ddot{\theta}_{1}=-\tau+p_{1} \times F \\
& I_{2}\left(\ddot{\theta}_{1}+\ddot{\theta}_{2}\right)=\tau+p_{12} \times F_{2} \\
& m_{1} \ddot{P}_{1}=F_{1}-F_{2}-\left[\begin{array}{c}
0 \\
m_{1} g
\end{array}\right] \\
& m_{1} \ddot{P}_{2}=F_{2}-\left[\begin{array}{c}
0 \\
m_{2} g
\end{array}\right]
\end{aligned}
$$

ここで, 各パラメータ及びジョイントと接地点に働く 力は

$$
\begin{aligned}
& \boldsymbol{p}_{1}=l_{g 1}\left[\begin{array}{l}
\cos \theta_{1} \\
\sin \theta_{1}
\end{array}\right] \\
& \boldsymbol{p}_{12}=l_{g 2}\left[\begin{array}{l}
\cos \left(\theta_{1}+\theta_{2}\right) \\
\sin \left(\theta_{1}+\theta_{2}\right)
\end{array}\right] \\
& \boldsymbol{P}_{0}=\left[\begin{array}{c}
-r \theta_{1} \\
r+y_{0}(t)
\end{array}\right]
\end{aligned}
$$




$$
\begin{aligned}
& \boldsymbol{P}_{1}=\boldsymbol{P}_{0}+l_{g 1}\left[\begin{array}{c}
\cos \theta_{1} \\
\sin \theta_{1}
\end{array}\right] \\
& \boldsymbol{P}_{2}=\boldsymbol{P}_{1}+l_{g 2}\left[\begin{array}{l}
\cos \left(\theta_{1}+\theta_{2}\right) \\
\sin \left(\theta_{1}+\theta_{2}\right)
\end{array}\right]
\end{aligned}
$$

である. $y_{0}$ は

$$
\begin{aligned}
& \left(m_{1}+m_{2}\right) \ddot{y_{0}}=-k_{c s}\left(y(0)-y_{0}\right)-k_{c d} \dot{y_{0}} \\
& -\left(m_{1}+m_{2}\right) g-m_{1} \frac{d^{2}}{d t}\left(\lg _{1} \sin \theta_{1}\right) \\
& -m_{2} \frac{d^{2}}{d t}\left(\lg _{1} \sin \theta_{1}+\left(\lg _{1} \sin \theta_{1}+\lg _{2} \sin \left(\theta_{1}+\theta_{2}\right)\right)\right)(31)
\end{aligned}
$$

を解いた結果求まる.

$5 \cdot 3$ バックラッシュ，時間とデータの標本化と量子 化，アクチュエータの制御方式の取り扱い ジョイ ント部の主にモータの減速機内部の歯車の噛み合いの 遊びに由来するバックラッシュは, メカニズムをモー 夕側と負荷側に分け，モータ慣性系と負荷慣性系の二 慣性系としてモデル化できる。 ${ }^{(3)}$

実機の制御システムでは, 計算機によりセンサデー タを読み, アクチュエータを制御する為, 計算機への 入力と出力に単純な制御周期の時間サンプリングや 計算による時間遅れ, デジタル量子化が存在する. そ こで, これらを含んだシミュレータを作成し，シミュ レーションを行う.

\section{6. 実ロボットによる検証実験}

上に提案した制御法の有効性を検証する為, 実験用 の2リンクロボットを構成して実験を行った.

\section{$6 \cdot 1$ 実験システムの構成}

6.1.1 機体のメカニズム 一次元の動作を行う 2 リンク 1 ジョイントのメカニズムのロボットを製作し た. 本機の外見写真を(図 8 )に示す. 上体は長さ $24 \mathrm{~cm}$ の一本のリンクにより構成され, その下端にジョイン 卜軸がある. 下体は, 軸の両側に固定された平行な二 つの棒状のリンク (長さ約 $10 \mathrm{~cm}$ ) よりなり, それぞれ のリンクの両端には, 地面の多少の凹凸や着地衝撃を 吸収する為の回転しないスポンジタイヤを取り付けた. この構造により, 各軸は, 正面から見ると常に水平に 保たれており, 側面から見ると下体は二個のタイヤで 地面と接している. 上体に取り付けたモータのトルク はベルトによってジョイントに作用し側面方向の運動 が発生する.

6.1.2 駆動系と制御系および姿勢センサ 上体 と下体の間のジョイントの駆動には Maxon 社製の DC モータ [24V,20W] と同社製のギヤヘッド [減速比 84:1] を用いた. 上体の地面に対する角度は, 上体に取り付 けた振動ジャイロの計測值を積分する事により測定

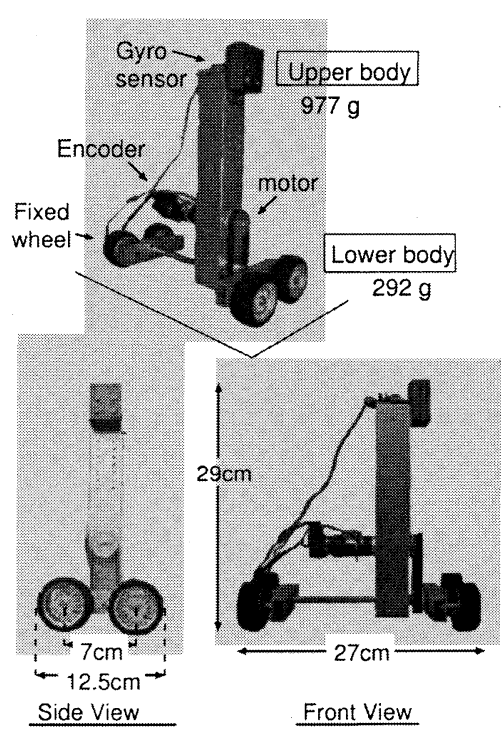

Fig. 8 The fabricated mechanism for experiment

し，下体と上体の間の角度は，モータに付いているエ ンコーダにより計測する. また, 下体と地面の角度は これらの二つのセンサデータの差として算出する.

コントローラには筆者らの研究室で開発された 12 ビットの $\mathrm{AD}$ コンバータとロータリエンコーダ用パ ルスカウンタ及び PWM ジェネレータを有するシング ルボードコントローラを用いた. モータの出カトルク の制御はフィードフォーワード計算に基づいて 0 から 255 までの 256 段階に量子化された PWM 比を与える 事により，モータ電流を制御して実現する．その制御 周期とセンサデータのサンプリング周期は 5 ミリ秒と した.

6.2 物理パラメータの測定とシミュレータの作成

6.2.1 モデル化とパラメータ測定＼cjkstart製作したロ ボットの物理モデル図 6 の剛体の浮遊 2 リンクと図 7 の下体にバネ・ダンパをもつモデルのパラメータの測 定を行った. 下体は，車輪の幅を持つ先の丸くなった 剛体リンク，上体は柱状の剛体リンクとしてモデル化 し，それぞれの重心位置と慣性モーメント及び長さと 重さを計測及び計算により求めた。 下体と地面の接触 部分は, 下体が跳ね返る距離が実機と同等な弾性を持 つバネ係数とダンパ係数 (図 7)を与えた. これらモデ ル化に用いられた各々のパラメータ值を表 2 に示す.

ジョイント軸の回転に伴う摩擦トルクは, ジョイン 卜角速度 $\dot{\theta}_{2}$ の関数として実測した結果を 7 次の関数に 近似してモデル化した. ギヤヘッドの仕様よりシミュ レーションにおけるバックラッシュの大きさは 1 [deg] 
Table 2 Parameter Values used in equation of motion

\begin{tabular}{|l|l|l|}
\hline Symbol & Numerical value & unit \\
\hline \hline $\mathrm{r}$ & $5.4 / 2$ & $\mathrm{~cm}$ \\
\hline$l_{g 1}$ & 3.5 & $\mathrm{~cm}$ \\
\hline$l_{g 2}$ & 15.5 & $\mathrm{~cm}$ \\
\hline$m_{1}$ & 292 & $\mathrm{~g}$ \\
\hline$m_{2}$ & 977 & $\mathrm{~g}$ \\
\hline$I_{1}$ & 5045.78 & $\mathrm{gcm}^{2}$ \\
\hline$I_{2}$ & 69097.11 & $\mathrm{gcm}^{2}$ \\
\hline$I_{r}$ & 10.4 & $\mathrm{gcm}^{2}$ \\
\hline$G_{p}$ & $84: 1$ & \\
\hline$k c s$ & 35000000 & $\frac{g}{\mathrm{sec}}$ \\
\hline$k c d$ & 108500 & $\frac{g}{\mathrm{sec}}$ \\
\hline
\end{tabular}

とした.

6.2.2 電子系のシミュレーション＼cjkstart実機では $5 \mathrm{msec}$ 間隔の制御ループにより，センサデータの観測 及び制御出力の計算を行う. 従って, シミュレータで も, 計算幾からの出力と入力は $5 \mathrm{msec}$ 間隔で行い，そ の間は, 出力は保持してシミュレーションした. アク チュエータは, 量子化した PWM 比を与えてアクチュ エータに流れる電流とトルクのシミュレーションを行っ た. ただし, 計算機への入力から処理, そして出力は 時間遅れが0とし，また，モータのエンコーダについ ては, 十分な分解能があるので, 連続として扱った.

$6 \cdot 3$ シミュレータによる制御パラメータの決定と結 果構築した詳細なシミュレータを用いて, 劣駆動 メカニズムを制御する為の適切なパラメータ，モード 1 から 2 へと遷移する踏み切り条件である上体の角度 と角速度，および，モード2の二つの制御パラメータ, の計四つの探索を行った. シミュレーションの結果, 一般にモード 1 からモード 2 に遷移する時の機体の姿 勢や角速度が，一歩の移動の正否に大きく敏感に影響 するが, ゲインの小さな差異が動作や着地姿勢に大き くは影響しない踏切条件も存在する事が分かった. そ こで, そのような踏切条件を採用して制御系を構成し た. シミュレータによる探索の結果, 得た踏切条件の パラメータは $\left[\dot{\theta}_{2}=30 \quad \theta_{2}=106.5 K_{p}=29 K_{v}=9\right]$ である.このパラメータを用いた時のモード 1 の詳細 なシミュレーション結果を図 9 に示し, 制御モード 2 と制御モード 3 の詳細なシミュレーション結果の一例 を図 10 に示す. 詳細なシミュレーションの結果の図 10 には, 制御系の設計で対象としてないバックラッシュ やタイヤのスポンジによる振動の影響が高周波の小さ な振幅で現れている. しかし, その動きは踏子切って からの劣駆動倒立振子の運動全体には大きな影響を及 ぼしておらず, 特に制御系の設計には考虑しなくても 問題ないと考えられた.
6.4 実機実験の結果と考察シミュレーションで 得られたパラメータを用いて制御系を構成し，実機に 実装した.しかし，それだけでは実機に安定した一歩 の動作を行わせることはできなかった. そこで, さら に実機上で実験を行いながら若干のパラメータを探索 をして僅かな調整を行った。 その結果，実機の制御用 のパラメータを $\left[\dot{\theta}_{2}=25 \quad \theta_{2}=105 \mathrm{Kp}=29 \mathrm{Kv}=9\right.$ ] とすることにより一歩の動作が実現された. 実機実験 の結果の一例を図 12 に示し, 図 13 にその時のスナッ プショットを表示する. シミュレーション結果と実機 の振るまいは, 移動の周期や PWM 值, 上体と下体の 角度と角速度が殆ど同じである事が分かる．ただし， 現段階では実機がシミュレータとほぼ同じに振るまい， 一歩移動後に安定に完全に止まる事ができるのは繰り 返し行った実験のうち 30 \%程度に留まっている。こ れは, サンプル周期を $5 \mathrm{~m}$ 秒とした事に等による実験 毎に僅かに異なるモード 2 の初期位置の変動, 制御器 やバッテリーとロボットを繋ぐコードの影響等が理由 と考えられる. 制御周期を短くし, 電源やコントロー ラを搭載した外部とのケーブル接続のない実機, 及び 適切な機体パラメータを持つを実機を作る事で, 現在 よりも確実な動作が実現可能と考える.

結論として詳細なシミュレータを用いた探索を行っ た上での, 実機を用いたパラメータ探索は, ごく少数 回の実験により実現されており，本稿で提案した制御 則とアルゴリズム，及びシミュレータを用いた実機の 制御パラメータの探索手段が有効である事が示された と考えている.

\section{7. まとめ}

本稿では, 単純な 2 リンク 1 ジョイント (アクチュ エータ) 機構である劣駆動システムに, 一歩の移動動 作を実行させるための制御の方法を提案した.

このメカニズムを一歩移動させる為には, 図 2 に示 すとおり, 上体を倒し込み, 適切なタイミングで上体 を逆向きに振り下体を引き上げる．次に，上体が起き 上がった姿勢を維持したまま下体を回転させ，下体を 再び地面に着地させて, 上体と下体共に静止する.

この動作を, 下体が横たわっている状態で上体の 1 リンクを傾ける制御をするモード 1, 下体が一点接地 になる倒立振子状態で, 上体を振り上げて下体を引き 上げ，上体を垂直に維持しながら下体を回転させる制 御をするモード 2, 下体が回転後に再び横たわった状 態で，上体を垂直に静止させる制御をするモード 3 に 分けて, 順次, 制御することにより目標動作を実現す る方法を示した. 制御モードを切り替える適切な条件 


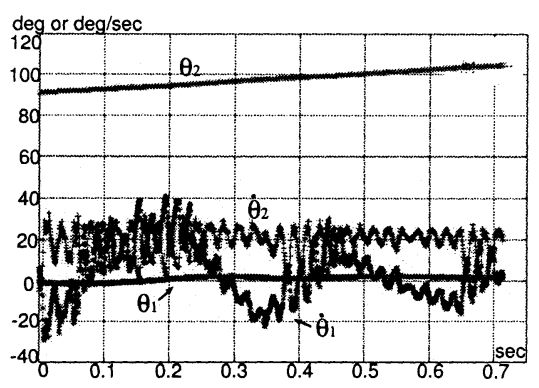

Fig. 9 A resultant motion of the mode1 in simulation

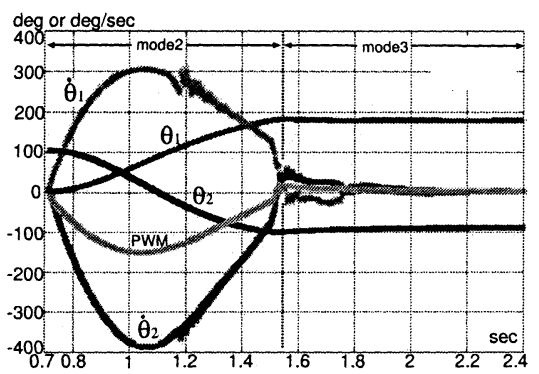

Fig. 10 A simulation result of Mode-2 and Mode-3

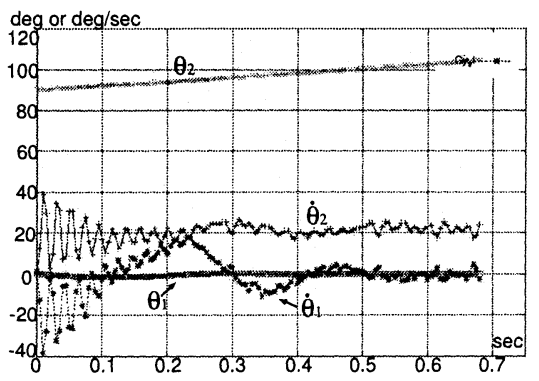

Fig. 11 A experimental result of the Mode-1 in real machine

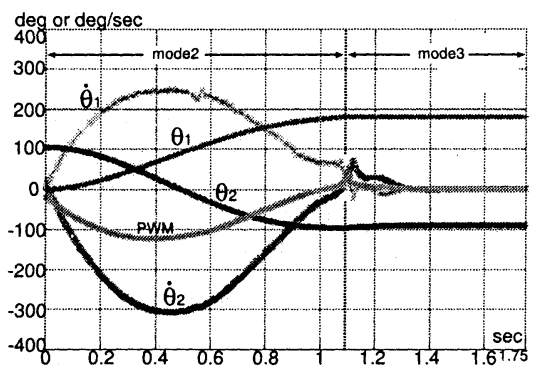

Fig. 12 A experimental result of Mode-2 and Mode- 3 in real machine

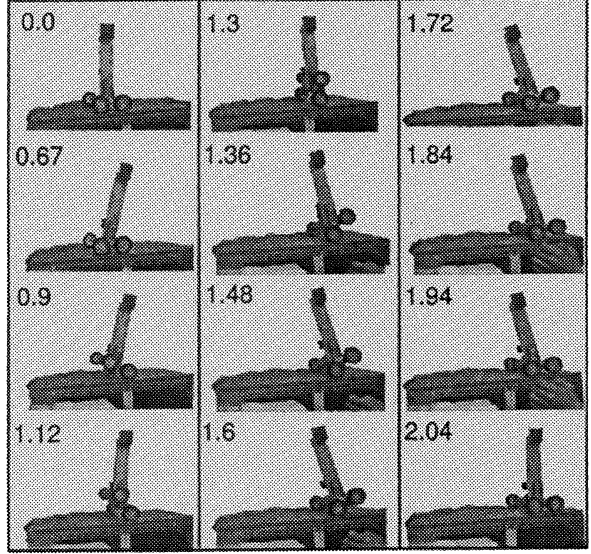

Fig. 13 The snapshots of an experiment of the successful motion by the real machine.(Number shows the time (second) after starting motion.)

と制御パラメータは, 制御入力を含めた力学モデルの シミュレーションを繰り返す事によって決定する.

提案した制御手法の有効性を検証する為, 機構を有 する実機を製作した，実機と同じ振る舞いをする詳細 なシミュレータを制作し, 制御で用いるパラメータを 決定した. 実機実験の結果, 四分の一の成功率ではあ るが, このメカニズムを有する実機に一歩を移動させ る事ができ, 提案した制御方法が有効である事が示さ れた. もちろん，この種のメカニズムの制御可能性や 容易さは対象とするシステム（機体）の形状や大きさ 等のボディパラメータに大きく依存する. 本研究では, このようなメカニズムの制御の一例を実機で実現する 事を目的として若干の試行錯誤に基づいて定めた機体 を例として検討を加えた. 制御が容易となる適切なパ ラメータの選択法については現在引き続いて研究中で ある.

\section{文献}

(1) Takei, Toshinobu. Yuta, Shin'ichi., An underactuated twolink-one-motor robot with dynamic mobility, IEEE/RSJ International Conference on Intelligent Robots and Systems (IROS 2005) pp.3510-3515.

(2) Mark W, Spong., The swing up control problem for the acrobot, IEEE Control Systems Magazine,Vol.15,No.2,(1995),pp.49-55.

(3) Umida Eijirou., Control \& Analysis of Torsional Vibration with Backlash, Journal of the Robotics Soiety of Japan, Vol.13,No.8,pp.1073-1077,1995 (in Japanese)

(4) Yoonkwon.Hwang,et al., Development of High Speed Dynamics Simulator for Humanoid Robots, Journal of the Robotics Soiety of Japan, Vol.23,No.1,pp.113-123,2005 (in Japanese) 